\title{
Экспертиза
}

КУРЮКИН Андрей Николаевич - кандидат политических наук, старший научный сотрудник Центра комплексных социальных исследований Института социологии Федерального научно-исследовательского социологического иентра Российской академии наук (117218, Россия, г. Москва, ул. Кржижановского, 24/35, корп 5; kuriukin@таil.ru)

\section{ПОЛИТИЧЕСКОЕ ДОВЕРИЕ В РОССИИ И США: ОПЫТ СРАВНИТЕЛЬНОГО АНАЛИЗА}

\begin{abstract}
Аннотация. Сегодня вопрос политического доверия выступает одним из ключевых в современном развитии политической системы и на этапе ближайшего будущего. Политическое доверие в России абсолютно персонифицировано, его основанием выступает субъективная оценка личных качеств, которая находится в маскулинно-протекторском измерении, а не в профессиональном. В США индивиды претендуют на комплексную оценку политического курса, формируемую СМИ, где оценки самого политика находятся на втором плане. Отсюда и вытекает центральная проблема современного политического доверия - размывание правды, что существенно затрудняет политическое самоопределение граждан. Ключевые слова: политика, доверие, политическое доверие, парадигмы, архетипы, глобализация
\end{abstract}

\section{Введение}

Вопрос политического доверия является сегодня одним из ключевых вопросов развития не только политической системы, но и всей современной цивилизации в целом. В наши дни, когда политическое напряжение во всем мире усиливается, большинство людей в целом соглашаются с демократическими идеалами и ценностями, которые важны для большинства стран мира. Однако в широком спектре случаев отмечается декларативность этих принципов, что, естественно, приводит к проблемам с определением политического доверия, которые основываются на расхождении между словами и конкретными действиями политиков и истеблишмента. Это и порождает все более и более активизирующуюся критику общественности в отношении политической системы за неспособность избираемых должностных лиц действовать транспарентно и подконтрольно обществу и его институтам. Таким образом, особенно важно рассмотреть вопрос политического доверия в двух ключевых странах современного мира - РФ и США, состояние и развитие которых с высокой степенью вероятности определит образ глобализированного мира будущего.

\section{Политическое доверие в Российской Федерации}

Рассматривая вопрос политического доверия в Российской Федерации, следует отметить, что на протяжении последних лет и сегодня оно держится на достаточно высоком уровне. Обобщенно это показывают исследования Института социологии РАН ${ }^{1}$. Так, по результатам мониторинга наибольшим доверием пользуются в России президент (около 69\%) и российская армия (около 65\%). Средним уровнем доверия в (40-45\%) пользуются в России правительство РФ, Церковь и Российская академия наук. В конце списка с показателями доверия в 15-25\% оказались политические партии, профсоюзы и СМИ. При этом необходимо отметить, что на протяжении последних 5 лет эти показатели не имеют существенной динамики. Также нужно зафиксировать, что по

1 Использованы базы мониторингового исследования Института социологии ФНИСЦ РАН «Динамика социальной трансформации современной России в социально-экономическом, политическом, социокультурном и этнорелигиозном контекстах», созданные при финансовой поддержке РНФ. 
результатам исследований Левада-Центра более $50 \%$ российских граждан оценивают направление развития страны как верное ${ }^{1}$.

Однако наиболее полно политическое доверие в России проявляется в персонифицированной форме - это доверие президенту России Владимиру Путину. Его позитивные оценки в общественном мнении начали складываться у граждан России практически сразу после вступления в должность и.о. президента России. В это время действующий президент РФ Б. Ельцин практически полностью утерял доверие как в элитах, так и в широких народных массах в связи с фактическим распадом его личности, откровенными провалами в политической деятельности, разрушением надежд на реформы, прогрессивное развитие страны и повышение уровня жизни, которые связывали с ним лично и его деятельностью огромные массы российского населения на протяжении начальных этапов его политической деятельности, и т.д.

В таких условиях практически сразу В. Путин и его команда стали реализовывать так называемую антипарадигму, в рамках которой по принципу «от противного» они проявляли все те необходимые качества, которых уже не было у Б.Н. Ельцина. При этом среди деловых качеств президента выделяли такие, как деловитость, работоспособность и энергичность - $13 \%$; ум и грамотность - $12 \%$; серьезность, ответственность и дисциплинированность - 9\%. В свою очередь, среди личных характеристик обращали внимание на такие качества, как воля, решительность, целеустремленность и напор - 17\%; спокойствие, уверенность и уравновешенность - 9\%. Наконец, в сфере нравственности были отмечены такие качества, как честность, открытость, прямота, порядочность 9\%; доброта - 3\%; интеллигентность, вежливость, простота, скромность - $3 \%$, твердость и принципиальность $-2 \% 2$.

За прошедшие десятилетия мир и Россия были ввергнуты в экономический кризис. Одним из главных участников этих событий был президент России Владимир Путин. Необходимо отметить, что за прошедшее время он также изменился как политик. Изменилось и общество. Осталась только высокая поддержка российскими гражданами своего президента, но в целом, т.е. в существенном виде, - при констатации внутренней трансформации.

По результатам опроса Левада-Центра, проведенного осенью 2017 г., на передний план выдвинулись уже личностные качества президента, реализуемые в его маскулинно-протекторском образе, что отразили в своих ответах $37 \%$ респондентов $^{3}$. Так, по мнению $19 \%$ из них, главными положительными качествами В. Путина выступают решительность, мужественность, твердость, воля, сила, спокойствие, смелость, четкость, уверенность в себе. В свою очередь, в рамках протекторского комплекса образа В.В. Путина $18 \%$ опрошенных называют грамотную внешнюю политику, выражающуюся в защите от Запада, которая вызывает уважение к нашей стране в мире, не позволяет «вытирать о нас ноги»; поддержку армии; обеспечение высокого престижа страны в мировом сообществе. При этом деловые и профессиональные качества президента и его личные качества, не связанные с маскулинностью, отошли на второй план. Так, $16 \%$ респондентов считают Путина опытным политиком и руководителем, сильным лидером, компетентным профессионалом. И наконец, $15 \%$ опрошенных указали на ум, образованность, интеллигентность и культурность как ведущие качества президента нашей страны.

\footnotetext{
${ }_{1}^{1}$ Общественное мнение - 2017. М.: Изд-во Левада-Центра. 2018. С. 126.

2 Качества В. Путина. Опрос населения. - ФОМ. 30.08.2000. Доступ: http://bd.fom.ru/report/map/ soc talk/soc talk20/d001922 (проверено 09.052018).

3 Жители России назвали лучшие качества Путина. - ИА REGNUM. 20.11.2017. Доступ: https:// regnum.ru/news/2346955.html (проверено 10.05.2018).
} 
В то же время оценки динамической составляющей образа президента, его поведения и деятельности по результатам этого опроса были следующими: $55 \%$ респондентов возложили на президента ответственность за проблемы, вставшие перед страной за период его правления, 20\% опрошенных выразили поддержку действий В. Путина как президента России, однако при этом $15 \%$ заявили, что президент не заботится о людях, мало делает для людей, не знает, как живут люди, забыл о простых людях. Причина такого положения, по мнению $42 \%$ опрошенных, заключается в том, что Путин получает неполную и искаженную информацию от своего окружения о ситуации в стране, а $16 \%$ участвующих в опросе считают, что правду о положении дел в стране от него скрывают.

Анализируя изложенное выше, следует выделить те конкретные основания, на которых строится столь высокий уровень доверия В. Путину. Можно констатировать, что первой чертой, которая субъективно привлекает если не всех, то очень многих в образе В. Путина, это его сила как политического лидера, подобно таким сильным и жестким лидерам, как Иван Грозный, Петр Великий, Иосиф Сталин. Другой объективной чертой характеристики современного российского президента выступает формирование в России среднего класса. В качестве еще одной объективной характеристики выступает улучшение социального благосостояния в России. Важной категорией доверия В. Путину является сегодня парадигма восстановления российской мощи. По его собственным словам, «мир смотрел на нас как на страну третьего мира на протяжении 1990-х годов, но сегодня мы - сила, с которой нужно считаться».

\section{Политическое доверие в Соединенных Штатах Америки}

«В Бога веруем!» (In God we trust!) - именно под таким девизом сегодня, как и последние 165 лет, формально живут Соединенные Штаты Америки. Однако, как показывает социальная и политическая практика, для американского общества уже последние 35-50 лет веры в Бога далеко не достаточно, а иным общественным институтам вообще «веры нет!». Особенно ярко продемонстрировала это динамика 2017-2018 гг. Так, сегодня в США уверенность в правильности действий национального правительства среди граждан снизилась на $14 \%$ по сравнению с аналогичным периодом 2017 г. Среди общественных институтов на 5\% (с 47\% до 42\%) понизилось доверие американским СМИ. Еще более, на $10 \%$ и $9 \%$ соответственно, уменьшилось доверие к деловым и неправительственным организациям ${ }^{1}$.

Бюро Эдельмана, которое уже в течение 18 лет опрашивает людей в США об их доверии к различным учреждениям, никогда прежде не выявляло таких серьезных падений рейтингов доверия. По словам Ричарда Эйдельмана, «это первый случай, когда массовое падение доверия не связано с насущной экономической проблемой или катастрофой, подобной ядерной катастрофе в Фукусиме. <...> На самом деле полная ирония в том, что это происходит в период процветания, с рекордными показателями фондового рынка и уровня занятости в США по сравнению с предыдущими годами» 2 .

Коренную причину такого положения следует усматривать в особой ситуации, которая сложилась сегодня в американском обществе. В наши дни, особенно с развитием сети Интернет, в США все громче и громче звучит недовольство, а иногда - и прямые обвинения тех или иных социально-политических акторов в создании ложных информационных сообщений, так назы-

\footnotetext{
${ }^{1}$ Edelman R. Edelman Trust Barometer. Global Report 2018. N.Y.: Edelman. 2018. 61 p.

2 Ibid. P. 20.
} 
ваемых фейковых новостей (fake news). При этом необходимо отметить, что оценка обществом новости как фейковой складывается на основе двуединства соответствия или противоречия ее политическим взглядам того или иного индивида или группы и ее точности, трактуемой как истинность или ложность конкретной информации, содержащейся в ней [American Views... 2018].

Рассматривая это явление подробнее, необходимо констатировать, что оно диагностировалось в США социологами и политологами на протяжении практически последних 20 лет. Однако наиболее отчетливый вид этот процесс принял только в последние годы. И поэтому возникает вопрос: «Кто же сегодня является основным носителем недоверия политическим институтам в США?» Ответ лежит в сфере категории «информированной общественности», т.е. это люди в возрасте от 25 до 64 лет, которые имеют высшее образование (колледж), регулярно потребляют новости и находятся в топ- 25 доходов домохозяйств для своих возрастных групп. При этом обнаруживается некоторый явный парадокс, который заключается в том, что в прошлом, 2017, году именно эта группа была главным оплотом доверия американским политическим институтам, а ее представители - главными носителями мировоззрения согласия с политикой президента и правительства и их поддержки. Однако уже в 2018 г. доверие к правительству в этой группе катастрофически упало - на $30 \%$, что моментально сделало именно их главными носителями политики недоверия правительству ${ }^{1}$. Еще более заметна катастрофичность недоверия американского общества национальным политическим институтам на примере сравнения с другими странами, где США продемонстрировали наиболее резкую динамику падения доверия за 2018 г. - на $37 \%$.

Наибольшим доверием национальные политические институты пользуются в КНР, где $84 \%$ респондентов (в рамках опроса по Edelman Trust Barometer) указали, что доверяют своему правительству. В это же время в ряде развитых стран (Великобритания, Канада, Австралия, Италия, США) отмечается резкое падение доверия своему правительству. Так, Д. Берсофф констатировал, что сегодня доверие политическим институтам связано не с их имиджем, а с ожиданиями, которые респонденты связывают с их деятельностью, и особенно с ее результатами. Для Китая такими факторами стало повышение мобильности и общего уровня жизни. В то же время, отметил он, непосредственная взаимозависимость между демократией и политическим доверием не выявляется, т.к. в то время как в традиционно считающихся демократическими странах (США, Великобритания, Франция) доверие падает, в странах, демократичность которых традиционно ставилась под сомнение (Индонезия, Турция, Малайзия, ОАЭ), доверие динамично растет [Bersoff 2018].

Подводя итог рассмотрению вопроса о политическом доверии в современных США, следует отметить, что в перспективе, по данным актуальных опросов, неуверенность в будущем будет составлять основу недоверия политическим институтам в американском обществе. При этом основными факторами будут выступать, опять-таки по результатам опросов, объективные неполитические факторы, такие как появление новых отраслей, роботизация уже имеющихся направлений экономики и глобализация. Уже сегодня многие респонденты эйдельмановского опроса говорят, что они не уверены в своем экономическом будущем, что оно выглядит довольно «тусклым» вследствие их нисходящей мобильности. Эти чувства находят свое выражение в успехе популистских политиков в Соединенных Штатах и Европе, которые обещают вернуть ситуацию предыдущих периодов с их кажущейся стабильностью, понятностью

1 Ibid. P. 24. 
и транспарентностью. В таких условиях, по словам Р. Эйдельмана, «Америка стремительно теряет свою политическую “землю обетованную”». Здесь речь идет уже не о поддержании демократии на прошлых уровнях, а о выживании всего американского общества ${ }^{1}$.

\section{Вместо заключения}

В дни, когда автор заканчивал работу над этой статьей, произошла встреча между президентом России В. Путиным и президентом США Д. Трампом. И американское, и российское общество подошли к этому мероприятию с различных сторон, что выразилось в различных ожиданиях. Со стороны российского общества эта встреча вызывала ожидание решения крупных проблем российско-американских отношений, мирового развития и международной политики. Ожидания американского общества можно охарактеризовать известной еще с XX в. формулировкой, по которой строились сначала желтая пресса, а позже - желтое телевидение: скандал, сенсация, шоу (Scandal, Sensation, Show - SSS). Центральным вопросом, интересовавшим американское общество (что особенно важно в ракурсе умножения фейковых новостей), был вопрос о вмешательстве российских спецслужб в последние американские выборы.

В то же время, несмотря на вакханалию в американской прессе и СМИ, замеры общественного мнения, постоянно проводимые компанией «Гэллап», показали, что больших изменений по вопросу доверия американцев Д. Трампу в форме одобрения или неодобрения его деятельности на посту президента не произошло. Так, за неделю до встречи рейтинги Д. Трампа распределились по схеме $43 \%$ к 52\%, а после нее (23-29 июля) - 40\% к 55\%. Эти данные показывают, что Д. Трамп имеет когорту последовательных сторонников. В отношении В. Путина можно констатировать, что картина с доверием к нему со стороны российского общества также отличается стабильностью. По данным ВЦИОМа, на неделе, предшествовавшей встрече, одобрение деятельность президента вызывала со стороны 63,4\% населения России; на неделе же, последовавшей за встречей, он составил 64,7\%. Это показывает, что президенты РФ и США имеют внутри своих стран серьезный кредит доверия, который слабо зависит от внешнеполитических ситуаций.

\section{Список литературы}

American Views: Trust, Media and Democracy. 2018. Gallup Inc. 68 p.

Bersoff D. 2018. Global Trust Monitor. UnCal Press. 95 p.

\section{POLITICAL TRUST IN RUSSIA AND UNITED STATES: AN EXPERIENCE OF COMPARATIVE ANALYSIS}

Abstract. The aim of this study is to form a comprehensive view of political trust, both in Russia and USA, as the most important factor in the progressive development of the society and political system in contemporary conditions of globalization. Political trust is considered as a process and result of the personal comprehension and evaluation of the policy,

\footnotetext{
${ }^{1}$ Friderman U. Trust Is Collapsing in America. - The Atlantic Daily. 2018. 21 Jan.
} 
political system and national leader. It is personal and socially conditioned. In Russia, political trust is deeply personified. In the USA the background of trust is an objective evaluation of «my personal future" (economic and social) in the context of political course of president's administration. The main part in forming this evaluation is the information from American media. That is why the crisis of political trust in USA is the crisis of national political media, and the problem of fake news is in the core of it. In these conditions, the US society can do some steps to the personification of political trust as Russian people do.

Keywords: policy, trust, political trust, paradigms, archetypes, globalization

АНДРЕЕВ Алексей Петрович - главный научный сотрудник Центра исследования проблем безопасности РАН (117335, Россия, г. Москва, ул. Гарибальди, 21б; andreev_a_p@mail.ru)

КОКУНОВА Светлана Дмитриевна - ведущий научный сотрудник Центра исследования проблем безопасности РАН (117335, Россия, г. Москва, ул. Гарибальди, 21б; svetlana.nukok@yandex.ru)

\title{
ВОПРОСЫ УКРЕПЛЕНИЯ ОБЩЕСТВЕННОЙ БЕЗОПАСНОСТИ В СВЕТЕ СОВЕРШЕНСТВОВАНИЯ РАБОТЫ ПО ПРОФИЛАКТИКЕ ПРЕСТУПНОСТИ НЕСОВЕРШЕННОЛЕТНИХ В СОВРЕМЕННЫХ УСЛОВИЯХ
}

\begin{abstract}
Аннотация. В статье исследуется вопрос об изменении структуры преступности несовершеннолетних, о роли нового поколения в социальном воспроизводстве и обеспечении общественной безопасности. Авторы анализируют современную статистическую карту преступности несовершеннолетних; обращают внимание на изменение правосознания нового поколения Z, обусловленное постоянным взаимодействием с информационными технологиями и влиянием сети Интернет, а также на смещение преступности в виртуальную среду. В статье делается вывод о необходимости новых подходов к профилактике противоправного поведения несовершеннолетних и формированию их правосознания в условиях новой формации.
\end{abstract}

Ключевые слова: общественная безопасность, постиндустриальное цифровое общество, социальное воспроизводство, преступность несовершеннолетних, правосознание

B опросы национальной безопасности страны, в т.ч. общественной безопасности, сегодня являются предметом изучения специалистов различного профиля - политиков, военных, правоохранителей, психологов, социологов, специалистов в области экономики, экологии, IT-технологий, медицины, кибернетики и др. Особую актуальность они приобретают в современную эпоху смены парадигмы общественного развития, связанной в значительной степени с информатизацией и цифровизацией всех аспектов жизнедеятельности человека.

В условиях перехода к новому технологическому укладу, ведущему к трансформации общества, существенно меняется динамика всех общественных процессов и явлений, которые приобретают новые свойства и формы и способны существенным образом повлиять на сложившуюся социальную структуру общества. В новой реальности важнейшая роль отводится новому поколению. Обладая бо́льшими информационно-технологическими образовательными возможностями, а следовательно и будущими компетенциями, молодое поко- 